\title{
Tourism in Gorkha: \\ A proposition to Revive Tourism After Devastating Earthquakes
}

\author{
Him Lal Ghimire*
}

\begin{abstract}
Gorkha, the epicenter of devastating earthquake 2015 is one of the important tourist destinations of Nepal. Tourism is vulnerable sector that has been experiencing major crises from disasters. Nepal is one of the world's 20 most disaster-prone countries where earthquakes are unique challenges for tourism. Nepal has to be very optimistic about the future of tourism as it has huge potentials to be the top class tourist destinations by implementing best practices and services. Gorkha tourism requires a strategy that will help manage crises and rapid recovery from the damages and losses. This paper attempts to explain tourism potentials of Gorkha, analyze the impacts of devastating earthquakes on tourism and outline guidelines to revive tourism in Gorkha.
\end{abstract}

Key words: Disasters. challenges, strategies, planning, mitigation, positive return.

\section{Background}

Gorkha is one of the important tourist destinations in Nepal. Despite its natural beauty, historical and religious importance, diverse culture, very close from the capital city Kathmandu and other important touristic destinations Pokhara and Chitwan, tourism in Gorkha could not have been developed expressively. Gorkha was the epicenter of 7.8 earthquake on April 25, 2015 in Nepal that damaged or destroyed the tourism products and tourism activities were largely affected. Tourism is an expanding worldwide phenomenon, and has been observed that by the next century, tourism will be the single largest industry in the world. Today, tourism is also the subject of great media attention (Ghimire, 2014:98). Tourism industry, arguably one of the most important sources of income and foreign exchange, is growing rapidly.

\footnotetext{
Dr. Ghimire has Ph.D. on "Pilgrimage Tourism Special Focus on Lumbini" from Tribhuvan University, Master of Science in Leadership for Educational Change (MSEd) from Bank Street College of Education, New York, a tourism writer and an educationist, statistician and academic leader with more than 27 year of experience in school/college management. Has published 100 's of articles in international and national journals, newspapers and magazines. Email: himghimire@gmail.com
} 
It is fair to say that tourism is one of the world's largest, if not the largest, nonbellicose industries (Tarlow, 2007; in Kunwar, 2016:1). Tourism involves elements of uncertainty and unpredictability that have always been in a way part of its attraction. Distance travelling has always involved risks, but the difference now is that these risks are progressively more evident (Moreira, 2007; in Kunwar, 2016:5).

Tourism industry has been experiencing major crises from disasters such as earthquakes, storm, tsunami, terrorist attacks, political instability, and economic recession. No tourist destination is immune to such crisis. The tourism business around the globe is one of the most susceptible and vulnerable sectors. Earthquakes occur with no warning and is unpredictable. Mostly, tourists plan their trips in advance and travel a long distance from their home. That is why, tourism activities cannot be closed in advance, nor can tourists be evacuated easily in case of emergency (Ghimire, 2016). Ghimire further writes that tourism plays a vital role in world business. Travel and tourism is one of the world's largest industries and generators of jobs. The tourism industry provides a wide range of employment opportunities, especially for women and young people, helping to break the vicious cycle of poverty by enhancing human capital and creating new prospects for future generations. The jobs are spread across a wide range of industries and comprise a broad range of remuneration levels (TRM, 2006).

\section{Tourism and Disasters}

Though tourism disasters have not been systematically studied from that perspective, it is evident that tourism areas, especially those which underwent rapid development, are particularly vulnerable to natural disasters; their location, for example on beaches or mountain slopes, their impact on basic environmental features, the absence of precaution or emergency procedures, and the often prevailing ludic atmosphere, expose them to sudden unexpected natural threats, which developers as well as their clients usually disregard or are unaware of (Calgaro \& Lloyd, 2008; in Kunwar, 2016:6). With global climate change, rapid economic development and accelerated urbanization, the pressures from resources, environment and ecology have been intensified on most countries in the world. In recent years, frequent world-wide natural disasters have brought about huge devastation to human society, life and property (Ying, 2011:1). Many sectors of tourism, such as visitor arrivals, employment, private sector profits, and government revenues and eventually further investment, can be impacted negatively when a disaster occurs in a tourism destination (Huang etal,. 2008; in Ying, 2011:2). Therefore, a promising sunrise industry that inevitably has to grow with disasters if it is to succeed has been attracting increasing scrutiny about its crisis management from the academic perspective. For many years scholars and experts have been constructing generic models of tourism crisis and disaster management, specifically 
since "models suggest that a strategic management and planning approach to crisis and disaster management can be beneficial for tourism planners and managers" (Ritchie, 2004; in Ying, 2011:2).

Nepal is one of the world's 20 most disaster-prone countries. Due to its location on the Alpide belt (Alpine-Himalayan), the country is highly susceptible to damage from a wide range of natural disasters including floods, landslides, and earthquakes. Contributing to the high risks are factors such as a lack of synchronization amongst government agencies, poor infrastructure, lack of public awareness, and rampant poverty, challenges that Nepal must face in improving its disaster preparedness (NDMRH, 2015:26). Tourism is a large and unique collection of industry sectors with special needs in disaster planning and recovery. Tourism is especially vulnerable to disasters and, being fragmented, often its response is difficult to initiate and coordinate (Mistilis \& Sheldon, 2005). The two mega quakes and their large families of aftershocks that are still showing their presence around have been great teachers for the Nepalese people. What is required, though, is deep insight, a strong motivation to learn and dedication to implement what is decided at the central level of disaster management. In fact, this was an opportunity for the government of Nepal, leadership and local bodies to test their capacity to handle the crises of this magnitude. But managing things has not been smooth. Managing a disaster of any scale or managing everything in a proper, systematic and agreeable way has been a challenge for a country like Nepal (Ghimire, 2016:38).

\section{Gorkha at a Glance}

Gorkha, the ancient untouched and captivating town of Nepal is 25 kilometer off road from the main highway (Prithivi highway) connecting Pokhara and Kathmandu. Gorkha is a picturesque hill- town as well as one of the districts of Nepal that has a rich history of its own. It is situated on a small mountain at the height of 3500 feet and offers a magnificent view of the Himalayan Peaks. Three major mountain ranges Manasalu, Annapurna and Ganesh Himal which include more than 40 mountains are found in the territory of Gorkha district. Some 300 years ago, Nepal was divided into 50 tiny states, and Gorkha was one of them. The then King Prithvi Narayan Shah started to unify Nepal into one kingdom during eighteenth century. Actually the then king Drabya Shah founded this kingdom in the year 1560. The history of modern Nepal begins from Gorkha. Gorkha is also the home of Gurkhas - the legendary brave warriors who fought with knives against guns. Prithvi Narayan Shah is known for gathering his Gorkha soldiers and battling to unify all of Nepal by taking control of the Kathmandu. After his amazing victory, in the $18^{\text {th }}$ century, Kathmandu became the capital of Nepal. The beautiful meadows set amidst shooting snow-clad peak and glaciers, tranquil pine and rhododendron forest with hospitable people would be a major attractions for luring the tourists and provide them life-time memory and 
experience of the Manaslu and the Gorkha region.'Manaslu Conservation Area' in Gorkha region is famous for rich bio-diversity and ecotourism activities.

\section{Gorkha in National Tourism Master Plan and Policy}

Nepal Tourism Master Plan (1972) played critical role of importance in the tourism history of Nepal. It identified the major tourism products of Nepal, suggested the potential places and activities suitable to these areas, outlined promotional strategies and institutional managements for further growth of tourism. The master plan has categorized Nepalese tourism in Sightseeing, Trekking, Nepal style, Recreational and International Pilgrimage. The plan has given high priority to develop Gorkha as an important tourist destination. It also focused for the opening up of the westward tour Kathmandu-GorkhaPokhara-Tansen-Lumbini-Chitwan-Kathmandu to increase the duration of stay and an expansion of sightseeing circular tours. Kathmandu, Pokhara, Tansen, Lumbini, Chitwan, Gorkha etc. were emphasized for the natural, interesting and exciting resorts areas. It also focused for the conservation and promotion of the traditional music, dance, customs and festivals that exist in Gorkha as well (Ghimire, 2009).

\section{Existing Situation of Tourism in Gorkha}

Gorkha is one of the potential tourist destinations with diverse touristic attraction, very close from Capital city and other popular tourist destinations such as Pokhara and Chitwan, linked with national highway. Pokhara draws almost 60 percentage and Chitwan draws almost 30 percentage international tourists visiting Nepal, however, what a petty situation that Gorkha draws only less than 5 percentage of total tourist arrival in Nepal. Gorkha has been a desired/popular destination for domestic tourists as well. Around 10 lakh tourists/pilgrims (90\% domestic and 10\% foreigner) visit Manakamana every year. However, there is no policy thrust, marketing plan among tourism entrepreneurs in Gorkha to attract more tourists. Even residents of Gorkha has dominant role in national politics and national planning, however, their effort was not adequate to develop Gorkha tourism and tourism infrastructure. Gorkha tourism could not have been a priority area of Gorkhali investors. There is only one star category hotel. Gorkha lacks a tourism master plan for the development of tourism.

\section{Tourism Attractions of Gorkha}

Gorkha district has been the center of attraction not only in Nepal but also among the people in the world because of its diverse attractions.

Manakamana Temple: Manakamana temple is one of the important pilgrimage sites of Hindus in Nepal. On a beautiful ridge south-east of the township of Gorkha lies the holy temple of Manakamana, the holy goddess of aspirations. This temple is thought to be one of the manifestations of the Hindu goddesses Bhagwati. People have a faith that the Devi fulfills all aspirations and wishes of her devotees, thus is also 
known as wish fulfilling deity. The Devi in fact rewards her devotes on reaching the shrine in both spiritual and physical exhilaration. The temple area owes quite a small bazaar with good views to its surrounding. One can enjoy mild climate and plenty of interesting walks down deep valleys and terraced fields. It is now a bustling bazaar that is growing rapidly every day. The temple has been easily accessible within 10 minutes on due to the introduction of the cable car. Manakamana temple is linked with cable car from the main highway on the way to Pokhara and Chitwan from Kathmandu and vice-versa. The cable car station lies in Kurintar which is $105 \mathrm{~km}$ west of Kathmandu. It is a four-hour uphill walk from a place called Anbu Khaireni on Kathmandu-Pokhra Highway which is one of the important trekking and sightseeing destinations as well. Manakamana is facilitated with a number of hotels and lodges ranging from average to luxurious. Thousands of pilgrims and tourists visit this temple every year.

Gorkha Palace (Durbar): The Gorkha Palace was the birthplace of Prithvi Narayan Shah, who was born in the central palace named Dhuni Pari. Gorkha palace is built on top of a hill at an altitude of 3281 feet (about 1000 meter). Among the sites to visit, Gorkha Durbar tops the list. This historical palace is a one-hour walk from the downtown Gorkha bazaar. The palace is purposefully located over a fortified hillock. The temple of Goddess Gorakhkali lies on the southwestern side of palace. There is a famous cave that is claimed as the shelter of the statue of Gorakhnath, the Tantrik sage, adjoining it. View of the palace building is one of Nepal's historical landmark, some buildings have interesting wood carvings portraying various romantic scenes. One could see the "eternal flame" that has been burning for many years, as it was lit straight after the unification of Nepal, with the hands of Prithvi Narayan Shah. The detailed woodwork and spectacular carvings make the Gorkha Palace a treasured piece of history and a popular sight in Nepal. The place is pictureperfect to have a view of Mansalu, Himalchuli, Annapurna and Ganesh peaks of Himalayas and panoramic views of the valleys. Nevertheless, the best place to have a view of the palace and peaks is Upallokot, a viewpoint made on a pedestal over the hill at the height of some 5000 feet. Visit to the Gorkha palace is possible when one climbs steps from the bottom of the hill, all the way to the top, climbing about one thousand seven hundred steps (1700), in about two hours. Climbing to the Gorkha palace is challenging, but the view on the top is rewarding and the way down is a lot easier.

Tallo Durbar: It is a large building built in mid $18^{\text {th }}$ century in the administrative heart of the town. It occupies the site where the old Gorkha palace stood before the arrival of the Shahs which is earmarked for a museum, Rani Pokhari (Pond), old market etc. are important sites near Tallo darbar in Gorkha bazaar.

Dashain Fulpati Procession: Fulpati procession is one of the important cultural events during Nepal's popular festival Dashain in Gorkha. On Fulpati ( $7^{\text {th }}$ day of 
Dashain) - special kind of flowers are brought from the Gorkha palace to the capital city Kathmandu. Prithivi Narayan Shah had moved the capital of Nepal from Gorkha to Kathmandu and had started a tradition of bringing fulpati from Gorkha. On Fulpati Day, there is an Army parade, Fulpati procession to Gorkha Durbar along with other religious and cultural activities which visitors may find interesting to observe.

Siranchowk (Shreenath Kot): Shreenath Kot is one of the very important sites in Gorkha. It is famous for historical, cultural and natural purposes. It is one of the best sightseeing destinations in Gorkha from where one can see the whole range of Himalayas. It is also famous for rhododendron forest. There are three forts on the top of the mountain and a jyogi gufa. It is also the birth place of brave Amar Singh Thapathe general of the Nepalese forces of western front in the Anglo-Nepalese War who fought for the sovereignty of the country. He is regarded as one of the national heroes of Nepal. There is a temple-Shreenath Mandali which is also a famous pilgrimage site.

Lig-Lig Kot: It is one of the important historical sites from where the seed of Shan Dynasty originated. It was one of the principality in which the king for a year used to be selected by organizing a race. The winner of the race Drabya Shah from Lamjung became the king of this place and founded Gorkha kingdom in the year 1560.

Lakhan Thapa Village: This village is the home of the first martyr of Nepal, Lakhan Thapa Magar, who was one of the first prominent resistors against the rule of the Rana regime. He worked vigorously to overthrow the Rana rule. He set forth revolutionary political vision to overthrown the autocratic rule of Jung Bahadur Rana. On 27 February 1877, Lakhan Thapa was given a death penalty hanging him on a tree by Rana government. Bungkot is his town which is about $10 \mathrm{~km}$ away by road form Gorkha Bazaar. Villagers offer warm and hearty hospitality to any visitors to this place.

Gufa (Caves): Caves are also attractions of Gorkha district. Gorakhnath Cave (Gufa) lies on the beautiful Gorkha hill. Gorakhnath, a celebrated $12^{\text {th }}$ century yogi revered as an incarnation of Shiva, is said to have meditated. It is believed that Gorakhnath was the hermit from whom the district derives its name. The Gorakhnath cave lies to the east of Gorkha Durbar. The cave is carved out of the solid rock and is among the most important religious sites for Hindus and Buddhists in Nepal. The cave is linked to the palace physically - by a flight of steps - and doctrinally, Gorakhnath being the guardian deity of the Gurkha kings and an ally in all their battles. This is believed to reflect a real connection between the warlike Gurkhas and the yogi, the latter having attained immortality through his unselfish care for an ailing prince. Likewise, Sita gufa is located at Swara VDC and spreads from Surpani, Auawang, Aruchanaute to Arughat in Gorkha. It is the biggest cave found in Nepal. The cave is situated at the elevation of $1165 \mathrm{~m}$ above the sea level. Sita Gufa itself is 
the most important attraction for Hindus and of course for all tourists. The site has tremendous significances. Once, we enter inside the cave, one is awestruck by the faith and devotion. The cave is really an amazing natural gift. Jyogi Gufa at Shiranchowk and Fu Gufa are other important caves in Gorkha.

Buddhist Monasteries: In the Northern part of Gorkha, there is a big Shringi monastery at the base of the Himalayan range in the Bihi Village. Likewise there are many other Gumbas like Rajan Monastery, Chamdi Monastery, Sama Monastery, etc. located in Chhekampar, Bihi, Prok, Lho and Sama Village Development Committees. The North part of Gorkha is noted for its historical Monasteries. The trek to these monasteries is adventurous and sometimes difficult as they are located in very high altitudes. These monasteries date back to as early as 1368 BS and 1394 BS during the reigns of kings Aditya Malla and Punya Malla respectively. The evidence of their time can be found in the copper inscriptions left out by these kings which also instruct coming generation by these kings to perform ritual ceremony in these monasteries.

Gorkha Museum: Gorkha museum is situated at Gorkha Bazaar. It has a wide range of collection of weapons and ammunition used by Prithivi Narayan Shah. It also houses personal belongings of Prithivi Narayan Shah along with his 52 feet long china (birth detail). Apart from these collections, it also has wide range of objects such as art, sculptures, coins and several other articles on display.

Barpak: Barpak village is situated upon the hill top about 1900 meter high from sea level at north of Gorkha approximately $45 \mathrm{Km}$ away from Gorkha in Nepal. A gravel road running on the bank of Darauti River connects Barpak to the district head quarter Gorkha bazar and national highway to Kathmandu and Pokhara. Barpak is known as village of late VC Capt. Gaje Ghale who won the highest honourVictoria Cross Medal in the second world war in Burma. There is a local myth that there was a Ghale King who ruled Barpak and the surrounding areas. Barpak has its unique historic significance despite its isolation from mainstream politics and bustling city life. Its breadth taking natural beauty can melt many hearts and draw many tourists from the world. The unique sloppy shape of the village with clustered stone tile-roofed houses could be one of the attractions to the people wishing to visit Barpak. However, Barpak is the epicenter of devastating earthquake on May 25, 2015 which had destroyed nearly 1500 households and 15 thousand population mainly with Ghale and Gurungs tribes. Barpak is one of the stopover village routes of trekking around Manaslu. There are so many possibilities of developing different type of tourism in Barpak as it has so much to offer to its guests. Its rich culture, warm and friendly people, breadth taking scenes of Himalaya watching Barpak, overlooking valleys of Darauti river and Treks to Dharkey Danda, Narad Pokhari or just a chill out tour around the village and many interesting festivals. 
Laprak: Laprak, a Guriung village is another wonderful, heavenly and exciting remote village of the Gorkha. It is situated in the hills at an altitude of 2,300 m above the sea level. The climate is moderate during March to September and the winter season is likely to be very cold with snow falling during the month from October to January. This village has their own Gurung language, culture and tradition. The houses are made by whole stones and the roof tops are covered by wood. However, Barpak a neighboring village is the epicenter of devastating earthquake on May 25, 2015 which had destroyed nearly almost all houses in Laprak. There are all locally produced food items such as grain, vegetable, potato, milk, maize, barley, wheat, millet, bean etc. The Lapraki Gurung village is one of the attractions for tourists visiting Manaslu Region. It is surrounded by blossom of a plant like rhododendron and other ever green shrubs. By an easy walk above the village, one can reach to the "Gurung Hill-Gopsepakha"-the view point at 3000m. One can see panorama, magic, mysterious and spectacular views, sunrise at the morning and many Himalayan range like Manaslu (8163m) Bouddha Himal (6672m) Himalchuli (7893m) Rupina pass (4643m) Shringi Himal (7187m), Ganesh Himal (7429m) and Langtang Himalayan range, Lamjung Himal, Annapurna range etc. from Laprak.

Narad Pokhari: Narad Pokhari is one of the important pilgrimage sites of Hindus. Visitors can go to Narad Pokhari from Barpak. It is believed that if one worships after taking bath here at Shrawan Shrangti, one's wish would come true. But there is a myth that one must go there once declared; nevertheless journey is believed to be very harsh through the challenging mountain path.

Manaslu Conservation Area (MCA): Manaslu Conservation Area (MCA) is one of the important conservation areas in Nepal. The Manaslu Eco-tourism Development Project has been working in the region since 1997. Bordering the Annapurna Conservation Area to the west and Tibetan Plateau on the north and the east, the Manaslu region lies in Gorkha District to the west of Kathmandu. Manaslu Conservation area is a habitat for 33 species of mammals including the elusive snow leopard, musk deer, and the Himalayan thar, 110 species of birds, 11 species of butterflies and 3 species of reptiles. There are ourism 2000 species of plants, 11 types of forests and over 50 species of useful plants. The bio-climatic zones vary from subtropical to Alpine. The altitude rises from a mere $600 \mathrm{~m}$ to the summit of Mt. Manaslu $(8,163)$, the eighth highest peak in the world. The main objective of the conservation area is to pass on benefits of tourism to the local community and reduce unfavorable environmental impacts through the development of eco-tourism.

Sirandanda: Sirandanda is situated at the hill top from where its name has been derived. One can reach Sirandada with a short hike of one hour from Bhachek. Major attractions of Sirandanda are: Nagepokhari, Dudhpokhari, Bhoteodar, Chima and tea garden. It also offers a magnificent view of sunrise and a stunning Manaslu range. 
The village has a rich diversity of medicinal herbs like nirmasi, jatamasi, rato unyu, yarsagumba, satuwa etc. Sirandanda is struggling to find its place in the tourist map despite the overwhelming scenic beauty of its landscape.

Dharche Danda: Dharche danda is the highest point of the lower Manaslu trekking route. It offers a breathtaking 180 degree panoramic view of more than 20 Himalayan peaks. Among Gurung community, Dharche danda (hill) holds a religious significance. They offer prayer to the hill deity to avoid natural calamities and no felling of trees is allowed in the area. It is also believed that if tourists offer prayer to the hill deity, they will be blessed with clear visibility and will ward off misfortune while they are on a trek. Some of the prominent peaks that can be viewed from the top of Dharche are: Annapurna, Annapurna I, Annapurna II, Bharatsikhar, Gangapurna, Machhapuchhre, Lamtang, Himalchuli, Buddha Himal, Sarang Peak, Malkunti Peak, Babu Himal, Sringi Himal, Ganesh I, Ganesh II and Ganesh III and many others.

Tsum Valley: Tsum Valley is a sacred Himalayan pilgrimage valley situated in northern Gorkha. Tsum comes from the Tibetan word "Tsombo" which means vivid. The trail heads up the valley of the Budi Gandaki River through wild and unexplored country inhabited mainly by members of the Gurung ethnic groups. Upper Tsum valley (part of the Inner Himalaya) open from Chhokangparo, where hospitality local people (Tibetan group "Tsombo") welcome you with traditional Tibetan Chiya (butter tea) and local meal. The Tsum Valley is extremely rich in cultural assets. The valley is dotted with Buddhist monasteries, chortens and mani walls. The longest mani walls (over 250km) are at Dzong and Phurpe. The valley preserves steps of the great Buddhist Yogi Chyuchin Milarepa and story about Guru Padmasambhava. The people here never slaughter animals, even as sacrifice to the gods. The Tsum Valley is surrounded by the Buddha Himal and Himal Chuli to the west, Ganesh Himal to the south, and Sringi Himal to the North.

Honey Hunting: Gorkha is very famous for adventurous and arduous traditional honey hunting practices. Arduous traditional honey hunters just hang on a rope and slide down to the middle of the massive rock/riff and hunt honey.

Lakes/Ponds: Lakes/Ponds are also attractions of Gorkha. Birendra Lake (3640 m.), Chhosong Lake (4000 m.), Kaal Lake (3500 m.), Kalchhuman Lake, Narad Kunda (Pokhari), Sano Dudh Pokhari, Thulo Dudh Pokhari, Sun (Sup) Pokhari, Tatopani, Bhulbhulekhar are important lakes and ponds in Gorkha. Likewise, Uhiya Hot Spring, Bhulbhule Khar Hot Water Spring and Machhakhola Hot Water spot are famous hot water springs in Gorkha.

View Points: Being a hilly district with high mountains, Gorkha has several viewpoints such as: Bakreshwori, Tandrang Kot, Uppalo Kot (Gorkha Bazzar), Liglig Kot, Lakang Kot, Shiranchowk (Shreenath Kot), Taku Kot, Dharche Danda (Sambai), Bhachchek and many more. 
Cable Car: Manakamana Cable Car is the first and only cable car in Nepal. It is situated on a prominent ridge overlooking the river valley of Trishuli and connects to the Manakamana Temple from Darechok, Chitwan. It serves thousands of pilgrims/ tourists and locals every day. The cable car to Manakamana temple has been a boon for the tourism development.

Facilities: Transportation is one of the important facilities required for tourism. Gorkha is connected with major cities of Nepal including capital city Kathmandu by a highway. It is very close from Kathmandu-Pokhara Highway and East-West highway. Most of the villages are connected with seasonal rough roads. Gorkha offers wide varieties of accommodation facilities suited for almost all types of travelers. Whether it is for backpackers or business executives, Gorkha's tourist standard hotels and lodges give everyone a comfortable stay. Some of the villages are providing home stay packages for visitors. Most of the villages are connected with national grid of electricity. Internet, bank, security, postal, newspapers and telephone facilities are in an adequate condition.

\section{Disasters}

Oxford dictionary defines disaster as a sudden accident or a natural catastrophe that causes great damage or loss of life. IFRC (2015) writes "disaster is a sudden, calamitous event that seriously disrupts the functioning of a community or society and causes human, material, and economic or environmental losses that exceed the community's or society's ability to cope using its own resources. Though often caused by nature, disasters can have human origins". Disasters can take many different forms, and the duration can range from an hourly disruption to days or weeks of ongoing destruction. A disaster occurs when a hazard impacts on vulnerable people. It is acknowledged that due to population growth, increased urbanization, greater use and dependence on technology and globalization, disasters are becoming more frequent and geographically diverse (Pelling, 2003; in Biran et al.; 2014).

Kunwar (2015) aptly written "Nepal earthquake - 2015: the year of trouble". It came after the 7.8 magnitude April 25, 2015 devastating earthquakes. It has given an idealistic message to the readers. As earthquake is natural disaster and natural disasters are out of human control. However, man-made disaster becomes sometimes more harmful than the natural disaster for a country like Nepal (Ghimire, 2016). Nepal has been suffering with political instability and conflicts for more than 20 years. The current crisis is the country's worst man-made economic disaster. The economy has been completely stalled for the past couple of months and the impact is much worse than the earthquake. Things have become unbearable for not only to the general people of Nepal but also to the tourists. It has been negatively affecting the tourism in Nepal because of blockage in Nepal India boarder and fuel crisis. The most important 
touristic, religious and historic sites such as Chitwan National Park, Lumbini (the place where the Buddha was born), Janakpur (the place where mata Sita was born) have become red zones. Taxi fares have gone up almost $100 \%$, and restaurants are no longer operating due to the lack of gas. Some hotels report only $10 \%$ occupancy rate in contrast with the $90 \%$ rate expected during this time of the year. Since tourism in Nepal is an important source of income for the government, the current crisis only worsens the dire economic situation of the country (Tourism Review, 2015). Had the concered instutions understood farsighted statement "the year of trouble" noted by Kunwar (2015), the country and general public would not have been suffered that much. Because of this current crisis, Nepal will suffer for another couple of decades that ultimately damage tourism industry and international tourism market badly.

\section{Natural Disasters in Nepal}

Natural disasters are forces of nature that causes catastrophic events (UNESCO, 2006; in Kunwar, 2016:7). Natural disasters are common in Nepal. The damage and negative impacts of April 25, 2015 devastating earthquakes (Epicenter Barpak Gorkha) and its aftershocks are significantly large in the history of Nepal (Ghimire, 2016:47). The casualties were over 8,790 and 22,300 people were injured. It is estimated that lives of eight million people (almost one-third of the population of Nepal), have been impacted by these earthquakes. Thirty-one of the country's Seventy Five districts have been affected, out of which fourteen were declared 'crisis-hit' for prioritizing rescue and relief operations; another Seventeen neighbouring districts were partially affected (NPC, 2015:11). In 20114, Nepal faced landslide creating blockage in Sunkoshi River (killed 156, injured 27 and displaced 436 people), avalanches in Mt. Everest (killed 25 men mostly Sherpa) and blizzards and avalanches in Annapurna circuit (killed 29) that hampered largely in Nepalese tourism industry. Among all of the other challenges in the development of tourism in Nepal, the natural disasters are the major challenges to be faced (Kunwar, 2015:24).

Nepal's tourism sector has suffered losses worth Rs 44 billion in the aftermath of the devastating earthquake and its aftershocks. These disasters have heavily damaged the infrastructure of tourism in Nepal, affecting not only the mountaineering, trekking and tour businesses, but also, many cultural heritage sites, shrines, pagodas, temples and archaeological sites-properties over hundreds of years old (Ghimire, 2015). The earthquake affected about 2,900 structures with a cultural and religious heritage value. Major monuments in Kathmandu's seven World Heritage Monument Zones were severely damaged and many collapsed completely. In addition, in more than 20 districts, thousands of private residences built on traditional lines, historic public buildings as well as ancient and recently built temples and monasteries were affected by the earthquakes, 25 percent of which were destroyed completely. The total estimated damages to tangible heritage amounts to NPR 16.9 billion (US\$ 169 million) (NPC, 2015). 
Table 1: Summary of Damage and Losses

\begin{tabular}{|l|r|r|r|r|r|}
\hline \multicolumn{1}{|c|}{ Subsector } & \multicolumn{2}{|c|}{$\begin{array}{r}\text { Disaster Effects (NPR } \\
\text { Million) }\end{array}$} & \multicolumn{2}{c|}{$\begin{array}{c}\text { Share of Disaster } \\
\text { Effects }\end{array}$} \\
\hline & Damages & Losses & Total & $\begin{array}{l}\text { Private/ } \\
\text { Community }\end{array}$ & Public \\
\hline $\begin{array}{l}\text { Heritages sites in 16 } \\
\text { districts }\end{array}$ & 7,875 & 1,409 & 9,284 & - & 9,284 \\
\hline $\begin{array}{l}\text { Monasteries \& historic } \\
\text { structures (older than 100 } \\
\text { years) }\end{array}$ & 5,300 & 530 & 5,830 & 5,830 & - \\
\hline $\begin{array}{l}\text { Monasteries \& historic } \\
\text { structures (less than 100 } \\
\text { years) }\end{array}$ & 2,835 & 283 & 3,118 & 3,118 & - \\
\hline $\begin{array}{l}\text { Temples in remote areas } \\
\text { Total }\end{array}$ & 900 & 90 & 990 & & 990 \\
\hline \begin{tabular}{l}
${ }^{*}$ Almost all the monasteries are under community ownership and management \\
\hline
\end{tabular}
\end{tabular}

Source: (NPC, 2015).

The overall impact of the earthquake on the tourism sector goes beyond the 14 affected districts, which have suffered significant physical damage to well-known tourism destinations like Chitwan and Pokhara in terms of a sharp fall in the number of tourists. The negative repercussions of the disaster are likely to translate into a reduced number of tourist arrivals over the next few years, reduction in tourist spending per day from US\$43 to US\$35 (as per industry sources), which will significantly affect revenues. Other nations that have experienced similar disasters have generally taken several years to recover fully with regard to tourist arrivals. It is estimated that the overall impact of the earthquakes on the Nepali tourism industry will be a reduction of about 40 percent on average over the next 12 months, and a 20 percent reduction in the next 12 to 24 months (NPC, 2015).

Table 2: Summary of Damages and Losses

\begin{tabular}{|l|r|r|r|r|r|}
\hline \multicolumn{1}{|c|}{ Subsector } & \multicolumn{3}{c|}{ Disaster Effects (NPR Million) } & \multicolumn{2}{c|}{$\begin{array}{c}\text { Share of Disaster } \\
\text { Effects }\end{array}$} \\
\hline & Damages & \multicolumn{1}{c|}{ Losses } & \multicolumn{1}{c|}{ Total } & Private & Public \\
\hline Hotels and others & 16,295 & - & 16,295 & 16,295 & - \\
\hline Homestays & 1,720 & 495 & 1,720 & 1,720 & - \\
\hline Eco-lodges & 415 & - & 415 & 415 & - \\
\hline
\end{tabular}




\begin{tabular}{|l|r|r|r|r|r|}
\hline Trekking trails & 426 & 5,711 & 6,137 & - & 6,137 \\
\hline Tour operators & 7 & $\mathbf{4 , 9 2 4}$ & $\mathbf{6 , 1 3 7}$ & - & - \\
\hline Tourism revenues & - & $\mathbf{4 7 , 0 1 3}$ & $\mathbf{4 7 , 0 1 3}$ & $\mathbf{4 7 , 0 1 3}$ & - \\
\hline Air transport revenues & - & $\mathbf{4 , 7 2 0}$ & $\mathbf{4 , 7 2 0}$ & $\mathbf{4 , 7 2 0}$ & - \\
\hline Restaurant revenues & - & $\mathbf{1 1}$ & $\mathbf{1 1}$ & $\mathbf{1 1}$ & - \\
\hline Total & $\mathbf{1 8 , 8 6 3}$ & $\mathbf{6 2 , 3 7 9}$ & $\mathbf{8 1 , 2 4 2}$ & $\mathbf{7 5 , 1 0 5}$ & $\mathbf{6 , 1 3 7}$ \\
\hline
\end{tabular}

${ }^{9}$ Losses under homestays are include under the housing sector and not include in the total

Source: NPC, 2015

\section{Devastating Earthquake's Impacts on Tourism in Gorkha}

Barpak village of Gorkha district was the epicenter of April 25, 2015 devastating earthquakes (7.8 rector scale) in Nepal. The main quake and more than 400 aftershocks (richter scale four or more) damaged tourism in Gorkha largely. Manaslu trekking route partly (40\%) damaged, cultural villages such as Barpak, Laprak are collapsed/damaged, partial damage in heritage properties such as Manakamana temple, Gorkha durbar, Kalika and Gorkhnath temple etc. The Manakamana temple and Gorakhnath temple have witnessed serious crack due to quake and they have been tilted. Earthquake-triggered landslides had damaged the Arughat-Machhi Khola trekking section. However, after the route was opened, the Sirdibas-Yarubagar road section was damaged by another landslide halting trekking activities. The route becomes more difficult during the winter due to heavy snowfall. The hotel business was badly affected by the earthquake. Except for a few hotels on the Arughat-Sirdibas stretch, hotels in other areas did not sustain major damage. All the hotels above Sirdibas are safe (Kaini, 2015).

Sapkota (2015) writes "After the catastrophic earthquake, I wasn't sure whether I should visit Nepal," said Alexandra, a tourist from Italy. "I was informed that the situation here is very bad. However, I decided to visit the country after consulting with my friends in Nepal. The situation here is far better than she had anticipated. "I visited various places in Kathmandu and Bhaktapur and now I am in Gorkha. There is no reason why people should be afraid of visiting the country", she added. Her husband, Stephen, said, "What worries me is that Nepal has not been able to utilize its resources properly. The country has so many beautiful places, Himalayas and historically significant heritage sites. Nepal can attract a great number of tourists if those can be managed properly." He opined that positive news about the country should be spread. "We need to inform others that the country is peaceful and beautiful even after the catastrophic earthquake. However, all foreigners hear about its destruction." 


\begin{tabular}{|c|c|c|c|c|c|c|c|c|c|c|c|c|c|c|c|}
\hline$\stackrel{2}{2}$ & 2 & $\mathbb{N}$ & $\begin{array}{l}\infty \\
\text { ț }\end{array}$ & $\hat{n}$ & $\psi$ & & in & in & $\stackrel{\beth}{\beth}$ & 워 & & & $\begin{array}{l}m \\
\hat{2} \\
\hat{i}\end{array}$ & $\begin{array}{l}10 \\
\infty \\
\infty \\
0\end{array}$ & $\begin{array}{l}\text { 우 } \\
\text { రి }\end{array}$ \\
\hline$\underset{\sim}{\stackrel{\Delta}{*}}$ & $\vec{\sim}$ & $\triangleright$ & 会 & ஃ & $\stackrel{\Re}{\sim}$ & $\Xi$ & $\stackrel{10}{\sim}$ & $\stackrel{\infty}{\circ}$ & $\stackrel{0}{\curvearrowright}$ & $\begin{array}{l}\overrightarrow{0} \\
\hat{\sim} \\
\vec{v}\end{array}$ & ڤે & $\infty$ & $\begin{array}{l}\infty \\
\vec{a} \\
\text { in }\end{array}$ & 융 & $\stackrel{\circ}{\circ}$ \\
\hline$\stackrel{n}{\stackrel{n}{\sim}}$ & 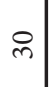 & $\triangleright$ & $\underset{+}{\stackrel{F}{F}}$ & $\hat{6}$ & 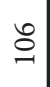 & $\stackrel{\infty}{-}$ & $\underset{m}{\infty}$ & శ̊ & శై & $\begin{array}{c}\tilde{m} \\
\dot{v}\end{array}$ & స్రి & 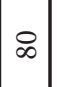 & $\begin{array}{l}\infty \\
\hat{\alpha} \\
\dot{f}^{2}\end{array}$ & $\overrightarrow{\tilde{\sigma}}$ & 仓ें \\
\hline 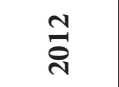 & $\stackrel{20}{=}$ & 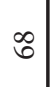 & $\hat{m}$ & $\tilde{\hat{n}}$ & $\infty$ & $\Xi$ & $\stackrel{0}{-}$ & 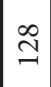 & 合 & $\begin{array}{l}\tilde{U} \\
\underline{-}\end{array}$ & ڤ̊ & $\stackrel{m}{m}$ & $\begin{array}{l}\text { के } \\
\text { के }\end{array}$ & 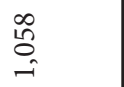 & $\begin{array}{l}\stackrel{\circ}{\circ} \\
\text { ले }\end{array}$ \\
\hline $\overrightarrow{\text { ) }}$ & $\infty$ & $\approx$ & $\stackrel{尺}{\stackrel{尺}{\sim}}$ & 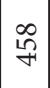 & 구 & $\infty$ & $\stackrel{\infty}{\sim}$ & $\begin{array}{l}\infty \\
i n\end{array}$ & $\vec{D}$ & 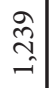 & ఫొ & $m$ & $\begin{array}{c}0 \\
\infty \\
\infty \\
\hat{N}\end{array}$ & 宫 & $\stackrel{\stackrel{\leftrightarrow}{\sim}}{\sim}$ \\
\hline 율 & $a$ & r & 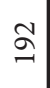 & $\underset{\sim}{\stackrel{\sim}{\sim}}$ & $\tilde{\sim}$ & $\exists$ & $\psi$ & $\overrightarrow{6}$ & ले & $\begin{array}{l}\stackrel{0}{\hat{~}} \\
-1\end{array}$ & $\stackrel{n}{n}$ & 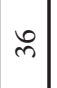 & $\begin{array}{c}\tilde{N} \\
\tilde{\sim} \\
\sim\end{array} \mid$ & $\stackrel{2}{\alpha}$ & 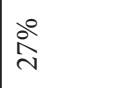 \\
\hline ठ্ণ & 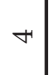 & $\infty$ & $\stackrel{\infty}{\infty}$ & $\stackrel{\infty}{\sim}$ & 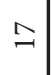 & 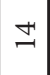 & 으 & 아 & ก) & $\ddot{n}$ & $\begin{array}{l}\stackrel{\sim}{N} \\
\text { N }\end{array}$ & $\Rightarrow$ & $\begin{array}{c}\hat{1} \\
\infty \\
\sim\end{array}$ & $\stackrel{\infty}{\stackrel{\leftrightarrow}{d}}$ & ذి \\
\hline 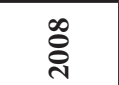 & กิ & $\simeq$ & $\underset{N}{*}$ & $\stackrel{\infty}{\infty}$ & $\stackrel{2}{\circ}$ & ' & $\exists$ & ঃ & ปี & $\begin{array}{l}\infty \\
\sigma\end{array}$ & $\stackrel{\leftrightarrow}{\mathrm{\omega}}$ & $\leadsto$ & 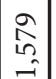 & \&o & $\frac{\circ}{\not \gamma}$ \\
\hline હ્ণิ & . & 0 & 20 & 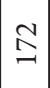 & $\exists$ & ' & $\underset{-}{\stackrel{8}{8}}$ & $\stackrel{\sharp}{\mathrm{N}}$ & $\hat{n}$ & స్ర & $\stackrel{\mathscr{q}}{ \pm}$ & $\infty$ & $\begin{array}{l}\varrho \\
=\end{array}$ & హี & 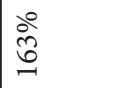 \\
\hline ๕̊̀ & . & ' & $\stackrel{m}{ }$ & $\stackrel{\sim}{\sim}$ & - & $\sim$ & , & $\sim$ & f & $\begin{array}{l}: \\
\stackrel{2}{2}\end{array}$ & in & -1 & $\stackrel{\mathscr{f}}{\sim}$ & $\stackrel{尺}{\unrhd}$ & $\underset{1}{\stackrel{\circ}{+}}$ \\
\hline$\stackrel{n}{\stackrel{\leftrightarrow}{̊}}$ & $=$ & ' & $\stackrel{\infty}{\sim}$ & $\vec{n}$ & ' & $\triangleq$ & 1 & - & $\approx$ & $\stackrel{\wedge}{m}$ & $\vec{n}$ & $\sim$ & $\stackrel{2}{q}$ & $\stackrel{6}{\circ}$ & $\stackrel{\stackrel{0}{7}}{\rightarrow}$ \\
\hline ஓ্ণ & $\sim$ & + & $\stackrel{m}{n}$ & $\vec{\sigma}$ & 10 & , & ' & $\sim$ & $\stackrel{m}{m}$ & $\begin{array}{l}\text { 을 } \\
\text { nn }\end{array}$ & $\mathbb{N}$ & , & 会 & ถิ & 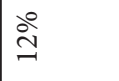 \\
\hline ๕̊ํํ & $\sim$ & $\sim$ & $\vec{m}$ & $\cong$ & $m$ & ' & $\sim$ & 1 & $\mathscr{F}$ & ๙̃ & $\vec{\sigma}$ & $m$ & $\stackrel{\sim}{\sim}$ & $\stackrel{\infty}{\wedge}$ & $\stackrel{\circ}{\infty}$ \\
\hline ઠิ & . & , & ஓి & $\underset{f}{*}$ & 0 & $\sim$ & + & ' & $\stackrel{\leftrightarrow}{\sim}$ & $\begin{array}{l}\text { הి } \\
\text { a }\end{array}$ & ส̄ & in & $\stackrel{+}{F}$ & $\begin{array}{l}\widehat{\infty} \\
\infty \\
\stackrel{\sigma}{0}\end{array}$ & $\stackrel{\stackrel{\circ}{F}}{\stackrel{P}{1}}$ \\
\hline ర్తి & . & , & $\stackrel{\infty}{+}$ & $\tilde{6}$ & $a$ & . & & 1 & $\vec{\sim}$ & 今̂ & 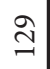 & ' & $\stackrel{\curvearrowright}{\infty}$ & $\stackrel{ }{1}$ & ذ্ं \\
\hline ๕્స & , & , & to & $\underset{(}{(}$ & $\circ$ & . & & . & in & $\begin{array}{l}n \\
n \\
n\end{array}$ & in & $m$ & fै & ชิ & $\stackrel{\circ}{\Rightarrow}$ \\
\hline Әे & $\sim$ & in & $\circ$ & $\infty$ & in & , & & - & $\stackrel{\Perp n}{\sim}$ & $\vec{n}$ & $\vec{\infty}$ & $\stackrel{m}{-}$ & $\begin{array}{l}0 \\
\infty \\
i n\end{array} \mid$ & $\stackrel{\infty}{\stackrel{m}{\sim}}$ & $\stackrel{\circ}{\stackrel{m}{m}}$ \\
\hline 章 & 氞 & 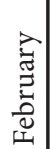 & $\begin{array}{l}\frac{\pi}{0} \\
\stackrel{0}{\pi} \\
\end{array}$ & 咅 & $\vec{\pi}$ & $\Xi$ & 를 & 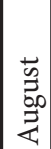 & 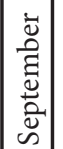 & 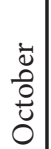 & 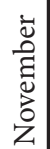 & 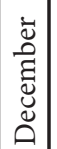 & 胥 & 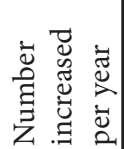 & 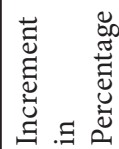 \\
\hline
\end{tabular}


Table 3 represents the number of trekkers visited in Manaslu Conservation Area from 1999 to 2015. The table also shows the number of tourists and percentage of tourists increased (or decreased) in following years. There has been increase in number of tourist since 2007 and the year 2007 has the highest increment of 163\%. Because of devastating earthquakes and aftershocks, the number of tourists is decreased heavily in 2015. If it is compared for six months (May to October), the number of tourist in 2013 is 3028, in 2014 is 3347 and in 2015 is 575 . Decrease in number of tourists impact negatively in foreign currency earning, employment, consumption of local products and many more.

Figure 1: Situation of Manaslu Trekking Route after Earthquakes and Its Aftershocks

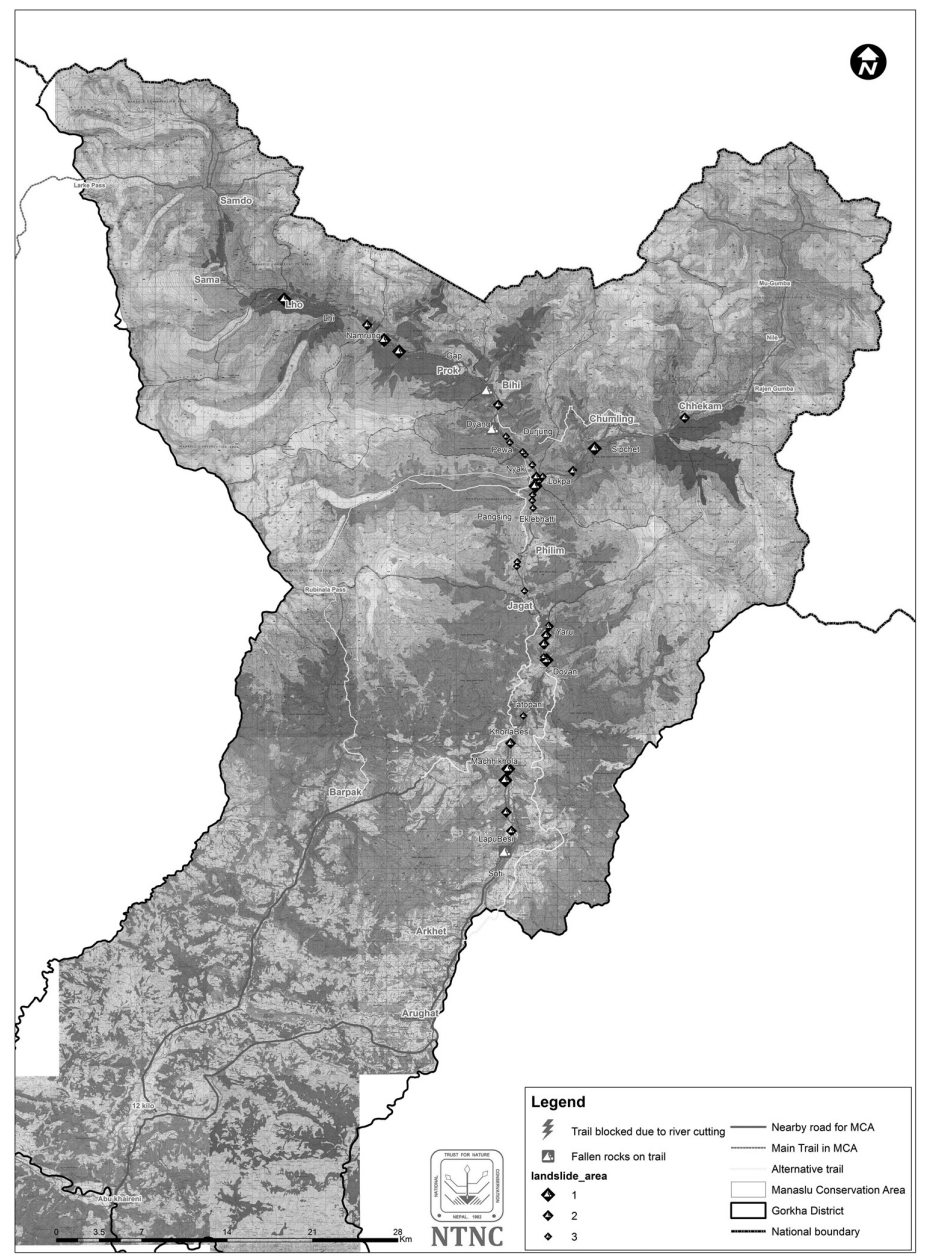

Source: NTNC, 2016 
Gorkha was the epicenter of the biggest quake and devastation is epic. Gorkha is significant place for growing domestic tourism with the biggest attraction of Manaslu Circuit Trek. By all developments, the trail was on its way to becoming a major one, with over 4000 trekkers a year. Growing stats stimulated construction of many new teahouses and lodges in the Manaslu area.

This region might remain negatively affected for a while. However, the trekking trails are repaired, alternative trails are being developed and climbers have started returning to Manaslu, the eight highest mountain in the world, four months after the earthquake. The number of aspiring climbers has been increasing.

\section{Prospective Tourism Products in Gorkha}

Gorkha district can be one of the important tourist hub with diverse touristic attractions in Nepal. It offers following tourism products.

Table 4: Prospective Tourism Products in Gorkha

\begin{tabular}{|c|c|}
\hline Category & Tourism products/activities \\
\hline \multirow{8}{*}{$\begin{array}{c}\text { Mountain } \\
\text { tourism } \\
\text { (Trekking and } \\
\text { Mountaineering } \\
\text { activities) }\end{array}$} & $\begin{array}{l}\text { Manaslu expedition }(8163 \mathrm{~m} .) \text {, eighth highest mountain in the } \\
\text { world }\end{array}$ \\
\hline & $\begin{array}{l}\text { Expeditions connected with other peaks such as Ganesh Himal, } \\
\text { Annapurna etc. }\end{array}$ \\
\hline & Trekking around Manaslu \\
\hline & Gorkha-Arughat-Jagat-Tsum Valley trek \\
\hline & Gorkha-Arughat-Jagat-Nubri La-Besisahar trek \\
\hline & Gorkha-Arughat-Barapak/Laprak-Rubinala Pass-Nyak trek \\
\hline & $\begin{array}{l}\text { Gorkha-Barapak/Bhachek-Dudhpokhari-Bichour-Besishar } \\
\text { trek }\end{array}$ \\
\hline & $\begin{array}{l}\text { Harmibhanjyang-Shiranchowk-Chipleti-Bhachchek- } \\
\text { Sirandada trek etc. }\end{array}$ \\
\hline \multirow{6}{*}{$\begin{array}{c}\text { Heritage/ } \\
\text { Historical } \\
\text { based tourism } \\
\text { products }\end{array}$} & Manakamana and associated sites \\
\hline & Gorkha Darbar and associated site \\
\hline & Ligligkot and associated sites \\
\hline & Shiranchok and associated sites \\
\hline & $\begin{array}{l}\text { First Prime Minister of Nepal Bhimsen Thapa's Village } \\
\text { (Borlang) and associated sites }\end{array}$ \\
\hline & $\begin{array}{l}\text { Other (Bhdhikot-Siddhathan/Dhuwakot, Ajirkot, Barpakkot } \\
\text { etc.) }\end{array}$ \\
\hline
\end{tabular}




\begin{tabular}{|c|c|}
\hline & Lakhan Thapa Magar Village (Bungkot) and associated sites \\
\hline & Kalu Pandey's village Khoplang \\
\hline & Arughat Bazar \\
\hline \multirow{3}{*}{$\begin{array}{c}\text { Cultural/ } \\
\text { Village Tourism } \\
\text { Products }\end{array}$} & Barpak, Laprak and associated areas \\
\hline & Betini-Tinmane Bhangyang and associated areas \\
\hline & Choprak-Numki-Bhachek and associated areas \\
\hline \multirow{16}{*}{$\begin{array}{l}\text { Pilgrimage } \\
\text { tourism sites }\end{array}$} & Manakamana temple \\
\hline & Gorakhkali and Gorakhnath \\
\hline & Bakreswori temple \\
\hline & Bhimeshwor Mahadev Mandir \\
\hline & Shreenath Mandali \\
\hline & Annapurna mai \\
\hline & Akala mai \\
\hline & Shivalaya, Nimel \\
\hline & Narad Pokhari \\
\hline & Dudh Pokhari \\
\hline & Hinang Thrangu Tashi Choephel Ling Monastery, Nurbi \\
\hline & Rajen Gumba \\
\hline & Shringi monastery \\
\hline & Chamdi Monastery \\
\hline & Sama Monastery \\
\hline & $\begin{array}{l}\text { Laprang Gumba ( } 700 \text {-year-old Buddhist monastery, destroyed } \\
\text { with a massive fire), Samagaun }\end{array}$ \\
\hline \multirow{7}{*}{$\begin{array}{l}\text { Adventure } \\
\text { tourism } \\
\text { products }\end{array}$} & $\begin{array}{l}\text { Rafting/boating in Budhigandaki, Daraundi Chepe and } \\
\text { Marshyangdi }\end{array}$ \\
\hline & Bungee jumping \\
\hline & Mountain biking \\
\hline & Hiking in the mid-hills and villages \\
\hline & Honey hunting \\
\hline & Palungtar Sky-driving \\
\hline & Gopsepakha (Laprak) Ultra-light \\
\hline
\end{tabular}




\begin{tabular}{|c|l|}
\hline $\begin{array}{c}\text { Other } \\
\text { prospective } \\
\text { tourism } \\
\text { products }\end{array}$ & Social and volunteering tourism \\
\cline { 2 - 3 } & Research and educational tourism \\
\cline { 2 - 3 } & $\begin{array}{l}\text { Agro-tourism (Traditional farming, animal husbandry, organic } \\
\text { farming, cardamom farming, tea and coffee farming etc.) }\end{array}$ \\
\cline { 2 - 3 } & $\begin{array}{l}\text { Sports tourism (Badare, Shreenathkot Stadium is under } \\
\text { construction, need to explore and construct other sports } \\
\text { complex in different villages), Gulf court in Siranchok, } \\
\text { Thalajung and Kafaldanda, Cricket stadium in Nimel etc. }\end{array}$ \\
\cline { 2 - 2 } & $\begin{array}{l}\text { MICE (Meetings, Incentives, Conferences, and Exhibitions) } \\
\text { tourism }\end{array}$ \\
\cline { 2 - 3 } $\begin{array}{l}\text { Tisaster tourism (Visit/research/contribute to villages that are } \\
\text { highly affected by earthquake) }\end{array}$ \\
\cline { 2 - 3 } Research & $\begin{array}{l}\text { Peace and Conflict tourism (Visit/research/contribute to the } \\
\text { villages that are highly affected by Ten Years Armed Conflict } \\
\text { in Nepal) }\end{array}$ \\
\hline $\begin{array}{l}\text { Gorkhas uniqueness is its historical, natural and socio-cultural } \\
\text { diversity. It has been developed as a common dwelling place } \\
\text { for the Mongoloid and Aryan people of different castes with } \\
\text { their own traditions alike. The area is the abode of rich cultural } \\
\text { heritage, unsurpassed beauty, and biological diversity. Crossing } \\
\text { over its thundering rivers with the help of ropes and suspension } \\
\text { bridges, passing beneath towering rock cliffs and through } \\
\text { dense jungle adds to new experiences. The topography changes } \\
\text { each day ascending through number of climatic zones into } \\
\text { rugged territory and hastily joining the barren lunar landscape } \\
\text { of Tibetan plateau. These diversities provide a best ground to } \\
\text { researchers for their studies }\end{array}$ \\
\hline
\end{tabular}

\section{SWOT analysis}

Present situation of Gorkha in reference to soon-be-world an important touristic destinations in Nepal is analyzed with the help of SWOT analysis as follow:

\section{Strength}

- Holding dominant role in politics, education, culture, ethnicity, history, pilgrimage and natural beauty

- One of the very important historical and archeological sites

- Birth place of King Prithvinarayan Shah who founded modern Nepal 
- Beautiful old palace known as Gorkha palace, goddess Kalika temple and Gorakhnath cave.

- Goddess Manakamana is highly noted as a wishful filling goddess throughout the country.

- Overlooking the snowy peaks of the Himalaya

- Nepal's first Cable Car

- Caves and local custom, culture and tradition

- Historical Gorkha Darbar museum

- Connected with national highway

- Very close from Kathmandu and other popular touristic destinations Pokhara and Chitawan

- Diverse geography (228m-8163m), biodiversity, diverse culture and ethnicity Weakness

- Lack of tourism master plan

- Lack of integrated packages with Pokhara and Chitawan

- Below average basic facilities in various tourist sites

- Lack of coordination among tourism stakeholders

- Lack of tourism development policy thrust

- Seasonality impact on tourism

- Lack of publicity and marketing plans

\section{Opportunities}

- National and international organizations might be interested to work for tourism development in Gorkha

- There would be increasing investment including joint ventures in tourism related industries such as hotels, resorts, homestay, airlines etc.

- Nepal government is in the line to develop Gorkha as an important tourist destination and integrate in the westward and eastward tourist circuits.

- Development and promotion of local products and agro-tourism

- More tourist, more earning and more employment

\section{Threats and Constraints}

- Despite its tourism potential, Gorkha has been unable to draw attention of tourism stakeholders and tourists. 
- Cable car has been a boon to draw the attention of pilgrims and visitors; however the preservation, development, management, sanitation condition of Manakamana temple is poor.

- Sitagufa (Swanra, Gorkha), probably the longest cave in Nepal has been unexplored and ignored.

- The forts in historical principalities like Liglig Kot, Siranchowk, Bungkot, Agirkot etc. are losing their history day by day. The artifacts are being destroyed or stolen which could be the attractions for historians.

- Tourism has not been developed in a planned manner. There is lack of networking among different sites, lack of peoples' awareness towards tourism, lack of proper marketing of Gorkha tourism nationally and internationally, lack of promotional activities and materials.

- Lack of package programmes and mostly unplanned/unorganized domestic tours,

- Poor accessibility and difficult terrain

- Lack of trained manpower for tourism activities etc.

- Lack of tourism master plan for overall development of tourism in Gorkha.

- Rigorous marketing and packages of other tourist destinations.

- Negative impact of mass tourism. Industrial expansion and urbanization in Gorkha.

\section{Vision and Mission of Implementation: Think Globally, Act Locally}

Despite devastating earthquakes, Nepal is as beautiful as before and its people are just as welcoming. Compare to tourism potential and attractions, damage and loss in tourism sector by the devastating earthquakes was not as massive as it came in media. Even after the earthquakes, most of the tourist trekking routes are safe and fine. Nepal has many places with touristic values and rich cultural traditions. There are some must-visit places so that tourists could understand the Himalaya culture and history in depth. It is the high time to explore Nepal and visit virgin destinations of Nepal. After the earthquake, several countries warned their citizens not to visit Nepal unless they were involved in rescue and relief. Natural disasters can have a devastating effect on tourism. The impact appears bigger than it is. As people from outside do not know the geography, they become confused over the extent of the disaster and the areas affected. The Tourism Ministry and the Nepal Tourism Board are failed to coordinate and organize various promotional programs including talks, slide shows, conference presentations, and public relation activities to revive tourism after the earthquakes in Nepal. The Nepali tourism industry requires a strategy that will help manage crises and rapidly implement recovery strategies. (Ghimire, 2016). 
Gorkha has been an important place not only from the history but also from the natural and geographical setup. It has been holding dominant role not only in politics but also in education, culture, ethnicity, history, pilgrimage and natural beauty. The devastating earthquake has damaged a lot in Gorkha. There is lack of tourism master plan in Gorkha. Now time has come to reconstruct and remodel Gorkha by promoting tourism. This is the time to think globally and act locally. Besides political, communal, religious barriers, all the Gorkhalies need to stand unitedly for the conservation, development and publicity of Gorkha internationally which can draw the attention worldwide. Gorkha has been one of the popular destinations for domestic tourists as well. North Gorkha has great tourism potentials for wilderness trek in the Tibetan cultural setting with its diverse ecosystem and rich cultural heritage. These Trans-Himalayan valleys can attract more tourists for trekking and mountaineering adventures. The world has been turned out as a global village. Policies, planes, promotional activities should reach out to globally; however, the stakeholders have to act locally. Natural beauty, local culture, arts, food, traditions have very important role to attract the tourists. Tourism being a show and service motive industry, special attention needs to be given. It is well known fact that first impression is the last impression. So the dress, appearance, cheerfulness and hospitality are the first impression a customer (tourist) receives. Physical, mental, personal and social qualities of staff need to be charming and cheerful, clean and tidy, polite, intelligent, humorous, knowledgeable, unbiased, commanding, confident, sincere, kind, honest, friendly, helpful and lovable. The popularity of Nepal for spectacular view, fresh air with virgin villages, innocent people and typical culture, good religious harmony between the religions, the colourful fairs and festivals with traditional music and dance celebrated round the year, anyone can feel brave and joyful as steps on the land of the brave Gorkhalies. Now the time has come to follow the footsteps of Lord Buddha who had once said that, "The one who does not act fast falls behind and fails" (Ghimire, 2009).

\section{Models to Follow for Better Tourism Return}

Tourism brings several good things to the country but equally poses many threats and socio-cultural and economical distortion which could be rather controlled by the implementations of the policies and actions but not just commitments (Ghimire, 2009). Responsible tourism is the tourism that creates better places for people to live in, and better places to visit. Cape Town Declaration 2002 on Responsible Tourism in Destinations defines responsible tourism as follows:

- generates economic benefits for local people and enhances the well-being of host communities, improves working conditions and access to the industry

- involves local people in decisions that affect their lives and life chances 
- makes positive contributions to the conservation of natural and cultural heritage to the maintenance of the world's diversity

- provides more enjoyable experiences for tourists through more meaningful connections with local people, and a greater understanding of local cultural, social and environmental issues

- minimizes negative economic, environmental and social impacts,

- is culturally sensitive, engenders respect between tourists and hosts, and builds local pride and confidence.

Responsible tourism is fast becoming a global trend. There is possibility to cash this opportunity for Gorkha district if all stakeholders plan properly. Whole district could be model tourism district in Nepal. Following could be the models to follow in Gorkha:

Visit Gorkha Year: Visit Gorkha Year could be one of the important event to promote tourism in Gorkha. When Visit Gorkha Year is declared, it makes a reason to visit Gorkha. There would be a big hope to build up the tourism not only in Gorkha but also in Nepal by this event. Definitely, this would be a mega event in Gorkha; the success of the event can achieve various outputs. The increase in number of tourist arrivals, increase in length of stay, development of infrastructure, worldwide publicity and active involvement of governmental and non-governmental organizations ultimately contribute for the sustainable development of Gorkha tourism. Visit Gorkha not only the reason to visit, it is the matter of pride for tourism stakeholders as well. Year 2017 could be declared as "Visit Gorkha Year". However, more ground/ preparatory works yet to be done.

Diamond Jubilee of Manaslu Expedition: Mount Manaslu is the highest peak of the Gurkha massif, and is the eighth highest mountain in the world. It is located about forty miles east of Mount Annapurna. The Manaslu region offers a variety of trekking options. The mountain's long ridges and valley glaciers offer feasible approaches from all directions, and it culminates in a peak that towers steeply above its surrounding landscape is a dominant feature. The popular Manaslu trekking route of 177 kilometres $(110 \mathrm{mi})$, skirts the Manaslu massif over the pass down to Annapurna. The Nepalese Government only permitted trekking of this circuit in 1991. However, the first ascent was made by T. Imanishi (Japan) and Gyalzen Norbu (Sherpa) in May 9, 1956. The government and tourism stakeholders should organize Diamond Jubilee of Manaslu Expedition for year 2016. This programme would definitely revive the tourism in Gorkha.

Model Tourism Village: Model village tourism has been successfully demonstrated and famous in neighboring districts Ghalegawn-Lamjung, Ghandruk - Kaski and 
Sirubari-Syangja. A management committee takes all responsibilities of the tourists like welcome, accommodation, sightseeing and guiding. The villages are kept very neat and clean, the accommodation is simple, but comfortable, with good bedding, as well as clean toilet facilities. Meals of daily fresh and organic food are eaten with the family, and each evening there is entertainment provided by the community, which is usually Gurung dance and song. The people are friendly, well education and are enthusiastic about tourism. Sirubari is a compact farming community village. The unique attraction of Sirubari is the fact that it is the model of growing new trend in tourism in Nepal. Some of the villages in Gorkha are culturally and historically richer than Sirubari. If those villages are developed and publicized, the approach could be a milestone for tourism development in Gorkha.

Home Stay: The latest trend of home stay has been practiced in different villages in Gorkha. However, the devastating earthquakes has severely damaged most of the cultural villages such as Barpak, Laprak, Thumi, Bhachchek etc. Local communities will be benefited directly by this type of tourism. It could be one of the important aspects to attract tourists in Gorkha. For this, reconstruction and resettlement in those village, training and support.to the host communities are needed.

Networking with Important Tourist Destinations: By developing networks among different sites number of tourists as well as length of stay increases. Gorkha is not very far from Kathmandu and close to other popular sites Pokhara, Chitwan and Lumbini. When there is integrated package with those sites, we can increase tourists in Gorkha. It could be the rest destination for those who have are travelling to Pokhara and Chitwan and have no prior plan to visit Gorkha as well.

Community Tourism: A community tourist program has already started in Gorkha. The area is full of natural beauty, panoramic views, green mid-hill trekking, unspoilt jungle areas, lakes, caves, waterfalls and flora (medicinal, scented and edible plants). One can experience diverse climate and geographical territory in Gorkha. It could be one of the alternative tourism paradigms in Nepal.

\section{Immediate Activities to Revive Tourism in Gorkha}

The concern authorities should start following activities immediately to revive tourism in Gorkha:

- Time bond preparation of Gorkha District Tourism Status Report with inventory and documentation of losses and damages on tourism sites

- Collaborate with Governmental agencies (Ministry, DDC, VDC) for infrastructural development that ultimately development/support tourism

- Create and disseminate positive message about tourism in Gorkha through various media to re-establish and reposition the image of Gorkha tourism. 
- Develop promotional and marketing plan to promote new tourism sites and packages

- Develop and implement resettlement plan based on the possible tourist itineraries such as major settlement in the tourist night stay places and tea house at every $2 \mathrm{~km}$ walking distance.

- Most of the villages are offering home stay facility, orientation and training courses on home stay facility management to the operators of home stay facility should be organized.

- Provide awareness training and encourage locals to preserve their culture.

- Develop attractive packages to NRN family members (at least a member of NRN family visit to Nepal and Gorkha this year)

- Develop attractive packages to Nepalese employees (government, nongovernment and private) to visit Gorkha

- Organize seminars, talk programmes, discussions, video shows, expert's visit to earthquake affected areas and other promotional activities to publicize Gorkha and attract both domestic and international tourists

\section{Long Term Actions and Activities for Tourism Development in Gorkha:}

- Design a plan for reconstruction/restoration of heritage sites and property

- Preservation and protection of historical and archaeological heritage sites, pilgrimage sites such as Manakamana temple, Gorkha Durbar, historical forts, temples, monasteries, etc.

- Reconstruction of houses as tea houses accommodation all basic facilities for the tourist with adequate space, light, height and facilities for kitchen, dining, lodging, kitchen garden, waste management, camping, visitor entertainment etc.

- Develop infrastructure and promote sky diving, ultralight, rafting, mountain biking, rock climbing, canyoning etc. in different parts of Gorkha

- Construction of more model homestay villages on trekking routes/trails

- Develop and promote tourism circuits connecting Pokhara, Tansen, Lumbini, Chitwan and Kathmandu

- Encourage investors to build standard hotels in Gorkha bazar (probably one hotel of one, two and three star hotels category)

- Educate people about sustainable and responsible tourism

- Preparation of Gorkha Tourism Master Plan 


\section{Integrated Settlement and Infrastructure Development Plan for Tourism Development in Gorkha}

- Classification and land pulling, settlement and reconstruction (Infrastructure, agriculture, tourism facilities, forest and greenery, green industry and local crafts, mining, etc.)

- Resettlement of homogeneous group (each settlement of Ghale, Gurung, Baram, Magar, Chettri, Brahmin, Bishowkarma etc.) along the rural trekking trails to protect and preserve their unique cultural and tradition.

- Strict follow up of traditional architectural design with earth-quake safety mechanism for the tourism villages and home-stays. Ensure that adequate space, light, height and spacious surroundings are provided.

- Keep agricultural land protected and intact and try to make houses in the suitable dry lands.

- Ensure allocation and /or protection of forest, river and other water sources in each settlement.

- Plan for basic utility and recreational infrastructures such as resorts, rural/ village recreational garden/park, fun and Children Park, police post, tourist information center, health-post, communication system, drinking water facilities, rescue center with helipad, cultural museum and cultural center etc. in each potential tourism village.

\section{Conclusion}

After the earthquake, several countries warned their citizens not to visit Nepal except if they were involved in rescue and relief. Nepal might be well prepared, but tourists also have to be prepared themselves like being well-informed about the intactness of tourist sites, their safety, and trustworthy rescue system. The government and private sector should coordinate and offer incentive packages to the tourists to revive and recover damages that will help boost the tourism. Nepalese embassies and diplomatic missions in abroad have been criticized a lot for their activities such as incapability in lobbing with international communities, branding of Nepal and act as real ambassador of the nation. Tourism ministry and Nepal Tourism Board have to coordinate with them and organize various promotional and awareness programs such as talks, slide shows, conference presentations, and public relation activities to promote tourism in Nepal. Primarily, it would be great way if they focus in neighboring countries India and China as they are the largest and emerging tourist market in the world. Further, regional tourism in Asian countries and in the west. One of the fact Nepalese tourism entrepreneurs should focus on pilgrimage, adventure and regional tourism which will be less affected by national and international incidents. 
The damages caused to the tourism sector in Nepal by the April 25 earthquake and powerful aftershocks were wrongly reported in the international community. Only some tourist sites suffered damages, while most destinations favored by tourists are remained unaffected. It is unfortunate that it has been miscommunicated among foreigners that almost all tourist destinations are damaged. Tourist arrivals in Nepal after the quake have been affected and declined, however, Nepal should take serious efforts to convince foreigners to visit Nepal and revive immediately. Likewise, the government and tourism stakeholders should seriously follow the code of conducts, modules and innovative activities to handle the difficult situation after disasters, strategies of risks and crisis management, and marketing plans for sustainable tourism development in Nepal.

Nepal has to be very optimistic about the future of tourism as it has huge potentials to be the top class tourist destinations. Tourists can experience, enjoy and feel the difference with diverse tourist attractions in Nepal. Gorkha tourism requires a strategy that will help manage crises and rapid recovery from the damages and losses. The message to develop tourism in Gorkha could be: "Each village is unique, each site is unique, each ethnicity is unique and each culture is unique." Develop it. Experience it! Quality service-quality tourist-quality return. Tourism is a boon in Gorkha, get benefit from it. Gorkha holding the greatest significance in tourism, is expected to play pivot role for the promotion of tourism in Nepal.

\section{References}

APEC (2006). Tourism Risk Management - An Authoritative Guide to Managing Crises in Tourism.

Asia-Pacific Economic Cooperation (APEC) (Retrieved from: http://www.crctourism. com.au/wms/upload/resources/aicst/06_twg_riskmgmt_Guide\%20eng.pdf)

Biran, A., Liu, W., Li, G., \& Eichhorn, V. (2014). Consuming post-disaster destinations: The case of Sichuan, China. Annals of Tourism Research, 47, 1-17 (Retrieved from: http://epubs.surrey.ac.uk/805641/1/Biran\%20Consuming\%20Post-Disaster\%20 Destinations\%20FULL\%2014-01-14.pdf).

Ghimire, H. L. (2016). Disaster Management and Post-quake Impact on Tourism in Nepal. THE GAZE Journal of Tourism and Hospitality. Kathmandu: International School of Tourism and Hotel Management (Affiliated to Salzburg University of Applied Sciences, Austria), 7 (1): 37-57.

Ghimire, H.L. (July 15, 2015). Naturally Nepal, Despite devastating earthquakes, Nepal is as beautiful as before and its people are just as welcoming. Kathmandu Post. Kathmandu: Kantipur Publications. 
Ghimire, H.L. (May 30, 2015). Bhukampapachhiko Nepalko paryatan. Kantipur daily. Kathmandu: Kantipur Publications.

Ghimire, H.L. (2014). Social Tourism: An Alternative Tourism in Nepal. THE GAZE Journal of Tourism and Hospitality. Kathmandu: International School of Tourism and Hotel Management (Affiliated to Salzburg University of Applied Sciences, Austria), 6 (1):98-118.

Ghimire, H.L. (2009). Tourism in Gorkha: A boon and challenges, Kathmandu: Gorkha Tourism.

IFRC (2015). What is a disaster? International Federation of Red Cross and Red Crescent Societies (IFRC) (Retrieved from: https://www.ifrc.org/en/what-we-do/ disaster-management/about-disasters/what-is-a-disaster/).

Faulkner, B. (2001). Towards a framework for tourism disaster management. Tourism Management, 22 (2): 135-147 (Retrieved from: http://www.ingentaconnect.com/ content/els/02615177/2001/00000022/00000002/art00048).

Kaini, S. (September 18, 2015). Climbers return to Manaslu. Kathmandu Post. Kathmandu: Kantipur Publications.

Kunwar, R.R. (2016). Tourism Crisis and Disaster Management. THE GAZE Journal of Tourism and Hospitality. Kathmandu: International School of Tourism and Hotel Management (Affiliated to Salzburg University of Applied Sciences, Austria), 7 (1): 1-36.

Kunwar, R.R. (2015). Tourism and Natural Disaster: A Study of Nepal's Earthquake -2015. Voice of Himalaya. Kathmandu: Mountain Academy Nepal, 4 (1): 19-37.

Kunwar, R.R. \& Limbu, B. (2015). Tourism and Earthquake: A Case Study of Nepal and Turkey. Kathmandu: NATTA Souvenir.

Mistilis, N \& Sheldon, P.J. (2005). Knowledge Management for Tourism Crises and Disasters (Retrieved from: http://wwwdocs.fce.unsw.edu.au/marketing/Mistilis05_2.pdf).

Momentum (October, 2014). Rebuilding tourism in the wake of disaster. Momentum The business magazine of UQ Business School (Retrieved from: http://www. business.uq.edu.au/momentum/rebuilding-tourism-wake-disaster).

NDMRH (2015). Nepal Disaster Management Reference Handbook (NDMRH). Center for Excellence in Disaster Management \& Humanitarian Assistance (Retrieved from https:// www.cfe-dmha.org/LinkClick.aspx?fileticket=xEUbtKHdfR4\%3D\&portalid=0).

NPC (2015). Nepal Earthquake 2015 Post Disaster Need Assessment. Kathmandu: Government of Nepal, National Planning Commission (NPC) (Retrieved from:http://www.npc.gov.np/web/new/uploadedFiles/allFiles/PDNAexcutiveSummary.pdf). 
NTNC (2016). Tourist data and situation image of Manaslu region. National Trust for Nature Conservation (NTNC).

Sapkota, N. (August 13, 2015). Quake-hit Gorkha gradually receiving tourists. Republica. Kathmandu: Nepal Republic Media (Retrieved from: http://www. myrepublica.com/society/story/26339/quake-hit-gorkha-gradually-receivingtourists.html)

Tharoor, I. (April 27, 2015). Nepal's other disaster: Its politics. The Washington Post (Retrieved from: https://www.washingtonpost.com/news/worldviews/ wp/2015/04/27/nepals-other-disaster-its-politics/).

Tourism review (2015). Fuel Shortage Hampers Tourism in Nepal. Tourism Review (Retrieved from: http://www.tourism-review.com/tourism-in-nepal-hit-by-fuelemergency-news4780).

TRM (2006). Tourism Risk Management (TRM) - An Authoritative Guide to Managing Crises in Tourism. APEC International Centre for Sustainable Tourism (AICST), UNWTO and PATA (Retrieved from: http://www.crctourism.com.au/ wms/upload/resources/aicst/06_twg_riskmgmt_Guide\%20eng.pdf).

UNEP (2008). Disaster Risk Management for Coastal Tourism Destinations Responding to Climate Change A Practical Guide for Decision Makers. United Nations Environment Programme (UNEP) (Retrieved from: http://www.unep.org/PDF/ DisasterRiskManagementforCoastalTourism_April_09.pdf).

UNISDR(2015).25April2015GorkhaEarthquakeDisasterRiskReductionSituation Report. The United Nations Office for Disaster Reduction (UNISDR). (Retrieved from: http://www.preventionweb.net/files/44592_gorkhaearthquakedisasterriskreducti. pdf).

Ying, L. (2011). Developing a Post-disaster Sustainable Tourism Model For Tourism Revitalization: Analysis ofSichuan's Responseto the Wenchuan Earthquakein 2008. (Retrieved from: http://r-cube.ritsumei.ac.jp/bitstream/10367/3920/1/51210001. pdf).

http://www.oxforddictionaries.com/definition/english/disaster 